reach the San Juan; and moved her up stream to within a league of where we were on the opposite slope of the ridge.

Note. The following paragraph should have been inserted on page 9, after the I3th line :

Our patron lived on the Okimunguidó, (sometimes abbreviated to Munguidó,) which enters the Atrato a short distance below Quibdo. He informed me that there is a much traveled path leading from the head of that stream, across the ridge of partition, to the Baudo, He was very desirous I should examine that route, until he found that I pronounced the partition ridge at the head of the Pato (in connexion with other considerations) to be an insurmountable obstacle. He reluctantly admitted, that at the head of the Okimunguido the ridge was much higher and wider than where we crossed it; and consequently, he desisted from his importunities that I should examine it.

\title{
A Description of the Sliding Caisson, at Her Majesty's Dock-yard, Keyham,
}

Devon. By Mr. W. Fairbarrn, M. Inst. C. E.*

The substitution of caissons, for the ordinary lock-gates, and their employment for closing the wide entrances of docks, have been somewhat extensively used, although the objections of occupying a considerable time, in having the water pumped out of them, and it being necessary to float them entirely away from the opening, before a vessel could pass, rendered them applicable only for special localities. The great width of opening required for the passage of ships of war, induced a rather general use of such caissons in the royal dock-yards; and at the new dock-yard at Keyham, where it was considered desirable to have the best accommodation for the newest class of large ships, the great breadth of the mouth and depth of the basin, induced the trial of a new form and arrangement of caisson, which should be of such capacity and dimensions as to resist the pressure of the water, effectually close the entrance, and still be so easy of manipulation as to admit vessels of war passing into the dock at any state of the tide.

The Keyham Docks were commenced in 1844, and they consisted principally of two capacious basins, with several entrances, or locks, from the sea. One of these, it was thought desirable to construct in such a manner, as to have the power of using it, when necessary, for a dry dock : its dimensions were 260 feet long, 80 feet wide, and 43 feet deep. The inner end, next the dock, was closed by a caisson of the ordinary form, and at the outer end, next the channel, the new caisson was tried.

The form of the caisson was that of a rectangular vessel, 82 feet 6 inches long at the top, 68 feet 6 inches long at the bottom, 42 feet high, and 13 feet 6 inches wide. It was built of wrought-iron plates, varying in thickness from $\frac{5}{8}$ ths inch at the bottom, to $\frac{3}{8}$ ths inch at the top ; well supported throughout by an inside frame-work of angle-iron, and gusset pieces, and by two decks of iron and one of timber for the interior arrangements; but which, at the same time, imparted great strength to the structure.

* From Lond. Journal of Arts and Science. June, 1854. 
The plates were connected by "butt-joints," with covering plates, attached by double and quadruple rows of rivets; and the bottom and ends were clothed with oak timber which bedded upon the cill, and against the jambs, when the caisson was in its place. The internal arrangements of the caisson were such, that when it was required to withdraw it from across the opening of the lock, by merely opening a valve, a sufficient quantity of water escaped from the upper chambers, to allow the body to rise a few inches from the bottom cill; when, instead of, as in the ordinary system, turning it round and floating it away, it was drawn back, by chains, transversely into a channel or opening in the masonry, at right angles with the lock,--leaving an opening of the clear span: and after the passage of the ship, it was drawn across again, and, by opening another valve, as much water entered as settled it securely on its bed or cill. This operation was stated to have occupied only eighteen minutes, for the passage of a line-of-battle ship; ten minutes for opening and eight minutes for closing. The total weight of the caisson was shown to be 290 tons : it contained 33 tons of iron ballast, and had an internal capacity for 323 tons of water. The mechanical arrangements were minutely described, and the general result appeared to have been very successful; and from the tabular statement of the deflexion of the caisson, under the pressure of various depths of water, the structure appeared amply strong for resisting either the dead pressure, or the concussions of the waves, which frequently beat heavily against the entrance of the docks.-Proc. Inst. Civ. Eng. May 9th, 1854.

\section{A MERICAN PATENTS.}

List of American Patents which issued from May 30th to June 20th, 1854, (inclusive,) with Exemplifications by CHarLes M. Kellen, late Chief Examiner of Patents ist the U. S. Patent Office.

\section{MAY 30.}

133. For an Improvement in Sewing Machines, Isaac M. Singer, City of New Yerk.

Claim, I I claim the method, substantially as deseribed, of forming a seam with one thread, by carrying the thread through the cloth or other substance, with the needle, and forming the thread into a loop, and at the next passage of the needle forming another loop, which is drawn through the first or previously formed loop. Also, the employment of lateral pressure, whether by a cam, a lever, or their equivalent, to act against and in combination with the needle, at or near the end of its perforating motion, substantially as described, and to insure the proper position of the needle. Also, in combination with a needle for perforating the substance to be sewed or stitched, and carrying the thread through it, a looping apparatus to form a loop at each perforation of the needle, and consecutively liberating the previously formed loop over the one last formed, to effect the concatenation of the stitches. And, also, the looping apparatus, with a recess, into which the thread is drawn to form a loop, or its equivalent, substantially as specified, in combination with the lever, or its equivalent, for alternately opening the recess to receive the thread to form the loop, and closing it to shut in the last formed loop, and discharging the previously formed loop over the one last formed. Also, giving a positive motion to the spring arm guide through which the thread passes from the tension apparatus to the needle, by edmining therewith the two bridles, or their equivalents, and the needle carxier, or some equivalent moving part of the machine, substantially as specified, the carrier

VoL. XXVIII.-THImD SERIAS. -No, 2.-AUGUST,.1854, 